Katrin Röder

\title{
Reparative Reading, Post-structuralist Hermeneutics and T. S. Eliot's Four Quartets
}

Suggested citation referring to the original publication:

Anglia 132 (2014), 1, S. 58-77

DOI: http://dx.doi.org/10.1515/anglia-2014-0004

Postprint archived at the Institutional Repository of the Potsdam University in:

Postprints der Universität Potsdam

Philosophische Reihe ; 115

ISSN 1866-8380

http://nbn-resolving.de/urn:nbn:de:kobv:517-opus4-94204 



\title{
Katrin Röder
}

\section{Reparative Reading, Post-structuralist Hermeneutics and T. S. Eliot's Four Quartets}

\begin{abstract}
This essay approaches T. S. Eliot's Four Quartets (1935-1942) from the perspectives of Eve Kosofsky Sedgwick's critical practice of reparative reading and of Paul Ricœur's poststructuralist hermeneutics. It demonstrates that Sedgwick's and Ricœur's approaches can be productively combined to investigate hermeneutic processes in which the textual energy of a dissemination of meaning is redirected by a reparative or integrative impulse. In Four Quartets, this impetus induces the creation of semantic innovation through a violation of semantic pertinence, that is, through novel, tensional and provisional connections between formerly separate textual elements and semantic units.
\end{abstract}

Katrin Röder, Universität Potsdam

E-Mail: kroeder@uni-potsdam.de

\section{Theoretical approach}

My approach to T. S. Eliot's Four Quartets is based on Eve Kosofsky Sedgwick's practice of reparative reading which was formulated in her essay "Paranoid Reading and Reparative Reading, or, You're So Paranoid, You Probably Think This Essay Is About You'. It appeared for the first time in 1997 as an introductory chapter to Novel Gazing, a collection of essays. Sedgwick's sketch of a method of reparative reading is a critical engagement with what Paul Ricœur has defined as a "hermeneutics of suspicion" (Ricœur 1970; Sedgwick 1997, 46), that is, with critical methods which, according to Sedgwick, prevailed in "New Historicist, deconstructive, feminist, queer, and psychoanalytic criticism" (Sedgwick 2003, 124-125). These methods comprise practices of reading which seek to expose structures of oppression and their ideological basis as well as the "binarisms" informing notions of sexual difference in the tradition of the "Lacanian calculus of phallic presence or absence" (Sedgwick 2003, 130-134, 138-143, 149; Sedgwick and Frank 1995, 1, 2, 20). The critical practice of reparative reading goes beyond this method of exposure. It reads texts and semiotic practices (e.g. camp) in terms of their empowering, productive as well as renewing potential to promote semantic innovation, personal healing and social 
change. Through its use of the "skill of imaginative close reading", it can complement the practices of reading which are dominated by a "hermeneutics of suspicion' (Barber 1997, 404; Sedgwick 2003, 145, 149-150; Lassen 2013, 83).

In the following, I seek to demonstrate that Sedgwick's methodology of reparative reading can be productively combined with Paul Ricœur's theory of reading. By extending Sedgwick's approach beyond its original domain (queer studies), this article does not investigate practices of signification which go beyond the exposure of binary conceptions of gender difference. Instead, it shows thas Eliot's Four Quartets connects religious, spiritual, philosophical and hermeneutic practices as well as affects which are otherwise defined as incompatible. ${ }^{1}$ I argue that the semantic and hermeneutic processes at work in Four Quartets are marked by a reparative and integrative hermeneutic impulse which "bestows plenitude" upon textual elements and which thereby resembles the hermeneutic practice of reparative reading. In the case of Sedgwick's method of reparative reading, this impulse "cements together and animates the amalgam of powerful part-objects" (Sedgwick 2003, 149, 150), that is, it generates new nexuses of meaning and novel self-images through feedback processes ${ }^{2}$ between formerly separate semantic units. My approach intends to contribute insights which might achieve a wider application of the method of reparative reading in the field of literary criticism.

According to Eve Sedgwick, "the methodological centrality of suspicion to current critical practice" with its "privileging of the concept of paranoia" (Sedgwick 2003, 125) as well as with its focus on negative affects (distress, anguish, fear, terror, shame, humiliation, contempt, disgust, anger and rage) has marginalized investigations of positive and neutral or "resetting" affects (interest, excitement, joy, enjoyment, surprise and startle). ${ }^{3}$ As a result, it has impoverished the "gene pool of literary-critical perspectives and skills" (Sedgwick 2003, 144). Although reparative reading offers a directional change in critical practice, it does not seek to replace but to "interdigitate" with the epistemological paradigm of paranoia (Sedgwick 2003, 145).

In her approach, Sedgwick challenges a number of "damaging a priori oppositions" which define paranoid methodologies by arguing that positive affects are productive sources of knowledge and that joy is a "guarantor of truth". In addition, she emphasises the immediate connection between affect and cognition and posits the political substance of affects (Sedgwick 1997, 1; Sedgwick 2003, 138).

1 On the importance of "affective variety", see Sedgwick 2003, 150.

2 Sedgwick's approach relies on Silvan S. Tomkins's cybernetic affect theory, see Sedgwick 2003, 133 and also Sedgwick and Frank 1995, 12-20.

3 Tomkins 1995a, 74. 


\subsection{Poststructuralist Hermeneutics and 'Reparative Reading'}

In the following, I seek to demonstrate that Sedgwick's method of reparative reading can be productively combined with Paul Ricœur's theory of reading. Robert Azzarello has recently pointed out a close connection between Ricœur's approach of 'restorative reading' in the last chapter of The Symbolism of Evil (entitled "The Symbol Gives Rise to Thought"), ${ }^{4}$ and Sedgwick's methodology of reparative reading (Azzarello 2012, 28). Azzarello emphasises a gradual difference between Ricœur's restorative paradigm (which contains elements of the 'hermeneutics of faith' discussed in Freud and Philosophy: An Essay on Interpretation) and Sedgwick's reparative one by pointing out the greater awareness of the intensity of damage done to queer selves, to societies and the environment on Sedgwick's side. The following discussion seeks to demonstrate that it is not so much Ricœur's notion of a 'restoration' of meaning but his theory of reading and his definition of semantic innovation as a "violation of semantic pertinence" which can offer a productive complementation of Sedgwick's approach of reparative reading for the following reasons:

1. because Ricœur's poststructuralist hermeneutics is flexible enough to acknowledge the intensity of damage done to selves, societies, cultures and the environment resulting from discrimination, the pressure of conformity, from prosecution, violence and pollution and so is, as I am going to argue in the final section of this essay, the ethics and hermeneutic practice which defines T.S. Eliot's Four Quartets and especially "Little Gidding”,

2. because it is a productive approach to polysemy and

3. because Ricœur's theory of reading - like Sedgwick's approach - investigates the construction of meaning "in front of the text" in acts of "imaginative close reading" and draws on the "heartbeat of contingency" (Ricœur 1973b, 140; Sedgwick 2003, 145, 147).

In his definition of 'distanciation' and 'appropriation' as the dialectic forces at work in creative processes of reading and writing, Ricœur emphasises that the work of art is not a reservoir of given meaning. Instead, it is constructed and thereby actualised as a "hierarchy of topics" (Ricœur 1973b, 135, 141) which is composed in acts of interpretation. According to Ricœur, every act of reading creates a "proposed world" (Ricœur 1973b, 140-141). Ricœur elaborates on this aspect of reading which constitutes the meaning of the text anew in every approach and which thereby changes the reader's experience of the world: "in hermeneutical reflection - or in reflective hermeneutics - the constitution of the self is contemporaneous with the constitution of meaning” (Ricœur 1991, 57). In

4 Ricœur's discussion of the power of symbols to give rise to meaning stands in the tradition of Ernst Cassirer’s conception of symbols as “Prägungen zum Sein”, see Cassirer 1923, I. 43. 
the second volume of Time and Narrative, Ricœur describes this creative aspect of reading in terms of its production of a surplus of meaning: "Only then does the literary work acquire a meaning in the full sense of the term, at the intersection of the world projected by the text and the life-world of the reader" (Ricœur 1985, 160). In Mario Valdés's words, the “convergence of the author's configuration of the text and the reader's refiguration is the dynamic merger that makes possible the net gain of new meaning in metaphorical writing” (Valdés 1991, 7). In his essay "What is a text?", Ricœur defines the act of intertextual reading as a hermeneutic practice which constitutes the text (Ricœur 1991, 57-58). For Ricœur, a text is not only an arrangement of signifiers, it comprises the meaning which is produced in acts of reading.

The following analysis seeks to demonstrate that Ricœur's poststructuralist hermeneutics can "interdigitate" productively with Sedgwick's method of reparative reading because Ricœur and Sedgwick assert that the reader's self is created anew in acts of reading (Ricœur 1973a; Ricœur 1984, 135; Azzarello 2012, 28; Valdés 1991, 57-58). ${ }^{5}$ In this way, Ricœur's and Sedgwick's approaches contribute to the "earnest noise" which defines ethical criticism, that is, to a "strategic blurring of standard boundaries ... between life and work, persons and texts" and "poiesis and academic exercise" (Buell 2000, 3-5). For Sedgwick, the act of reparative reading creates novel and subversive nexuses of meaning through connections of formerly separate semantic units as well as novel, provisional, deviant, subversive and alternative self images. ${ }^{6}$ It is an empowering experience of joy, surprise and even hope because it "gives the reader room to realize that the future may be different from the present" (Sedgwick 2003, 146). In addition, Sedgwick emphasises that Melanie Klein's psychotherapeutic work with patients who suffered from paranoid-schizoid dissociative disorders was based on creative hermeneutic processess of reading in which patients engage in a reparative reframing and semantic enrichment of "murderous partobjects", that is, of parts of persons which patients used to associate exclusively with negative affects: For Klein

\footnotetext{
the depressive position is an anxiety-mitigating achievement that the infant or adult only sometimes, and often very briefly, succeeds in inhabiting: this is the position from which it is possible in turn to use one's own resources to assemble or repair the murderous part-objects into something like a whole - though, I would emphasise, not necessarily like any pre-existing whole. Once assembled to one's own specifications, the more satisfying object is available both to be identified with and to offer nourishment and comfort in turn. Among Klein's names for the reparative process is love. (Sedgwick 2003, 128)
}

5 See also Paul Ricœur 1973a.

6 For the term "self image", see Tomkins 1995b. 


\subsection{Poststructuralist Hermeneutics, Deconstruction and Midrash}

In 2010, Kinereth Meyer and Rachel Salmon Deshen have developed a hermeneutic approach which draws on Ricœur's theory of reading and which can be linked productively with Sedgwick's method of reparative reading. In addition, Meyer's and Deshen's approach relies on the tradition of midrash and investigates the production of irreducible polysemy and indeterminacy at the interstices of texts (Meyer and Deshen 2010, 8). At the same time, however, it goes beyond methods of reading which provoke a disintegration and evaporation of meaning (Barthes 1992, 1132) and probes into the open-ended hermeneutic processes in which flexible and tensional wholes or "new overreaching nexuses of meaning" are constructed through connections between contrastive semantic units and textual elements (Stern 1988, 150). Like Ricœur's and Sedgwick's approaches, midrash with its use of a technique of "atomization" is characterised by a creative approach to polysemy and by an acknowledgement of the relative autonomy of discourses and semantic units (Stern 1988, 138-139; Meyer and Deshen 2012, 20). By defining intertextuality as a "virtual exegetical principle" in rabbinic hermeneutics, Meyer and Deshen have successfully demonstrated parallels between midrash and Eliot's Four Quartets. Relying on Meyer's and Deshen's analysis of Four Quartets, I would like to show that especially Eliot's "Little Gidding”, composed in 1941-1942 and thus shortly before what Sedgwick has called "the moment of the 'cybernetic fold"” (Sedgwick and Frank 1995, 20), is defined by a form of hermeneutics which relies on intra- and intertextual feedback processes and which already contains important aspects of Ricœur's poststructuralist hermeneutics as well as of Sedgwick's method of reparative reading.

Written at a time when Melanie Klein investigated processes of reparation in psychoanalysis, Eliot's Four Quartets and some of his works on cultural philosophy, above all The Idea of a Christian Society (1939) and Notes towards the Definition of Culture (1948), partake in the development of a cultural paradigm of reparation in the humanities. In his essay "Religion Without Humanism" (1930), Eliot criticised the shortcomings of traditional psychology and the social sciences with regard to their futile attempts to produce "unified individuals in a world without unity":

Analytical Psychology ... can do little except produce monsters; for it is attempting to produce unified individuals in a world without unity; the social, political, and economic sciences can do little, for they are attempting to produce the great society with an aggregation of human beings who are not units but merely bundles of incoherent impulses and beliefs. (Scott 1994, 63). 
When Eliot was working on Four Quartets and was acknowledging his personal state of depression in the prospect of the Second World War (Eliot 1939, 274) Melanie Klein and her student Donald Winnicott were developing forms of psychotherapy which provided alternatives to the rigid notion of the essentialist, stable, rational and autonomous core self. The goal of Melanie Klein's psychotherapy was a tensional and provisional integration of dangerous part objects which could generate novel, flexible and alternative self images (Sedgwick 2003, 128, 138).

The following analysis of Four Quartets seeks to demonstrate that the poem as a whole and especially "Little Gidding", composed under the impact of the Blitz and in an atmosphere which was characterised by a variety of affects, participate in the development of a cultural paradigm of reparation which spans innovative forms of poetry and new approaches in psychoanalysis, cultural philosophy and the natural sciences. There is at least one explicit link between the reparative paradigms in psychoanalysis and in Eliot's poetry: Christopher Reeves has demonstrated how ideas and even expressions from Four Quartets found entrance into Winnicott's psychoanalytical works through acts of imaginative reading and through a creative 'partial appropriation' of Eliot's text (Reeves 2010; Ricœur 1976, 43-44).

\section{Meaning Construction in Four Quartets}

The processes of understanding and of meaning construction are central subjects of Four Quartets. They are often discussed by personal voices in the text but they are also part of its impersonal passages ("East Coker" V.171-189; "Burnt Norton" V). William D. Melaney has argued that the presence of personal voices in Four Quartets is an expression of a new "poetics of self" which in part modifies Eliot's earlier programme of impersonal poetry formulated in "Tradition and the Individual Talent” (Melaney 2002, 148). However, it is important to emphasise from the perspectives of reader-response theory and reparative reading that the heterogeneous positions expressed in the personal passages do not add up to closed conceptions of a core self (Sedgwick and Frank 1995, 6, 12; Barber 1997, 402-405), of a "lyrical I" or of an "implied author" (Nünning 1993). The personal voices in Four Quartets are subjective and communal at the same time, they are related to as well as contain a great number of other voices: in the first section of "The Dry Salvages", the first person plural perspective contains a "sea" of repressed voices, i.e. the voices of victims of violence and oppression in history which express a plenitude of different historical and cultural viewpoints (“The Dry Salvages” I.15-39, 112-117). 
In Four Quartets, the hermeneutic processes of meaning construction are often discussed in the form of internal monologues or rather internal dialogues. Sometimes, the personal voices address counterparts in a very committed way on a metapoetical and metahermeneutic level, they open the text for a dialogue with readers: "You say I am repeating/Something I have said before. I shall say it again./Shall I say it again? ("East Coker" III.133-135). The discussion of the processes of textual understanding and of meaning construction in Four Quartets acknowledges experiences of ineffability and illegibility ("The Dry Salvages” II.96-103; "Little Gidding” V.224-227). At the same time, it encourages readers to participate in infinite processes of meaning construction through acts of imaginative reading. Eliot's poem shows that these positions need not be mutually exclusive: The experience of illegibility (the confrontation with the "illegible stone") gives rise to new processes of meaning construction which do not give access to an original meaning but to infinite acts of interpretation ("Little Gidding” V.224-227).

\subsection{Dancing Images: Four Quartets as a Provisional Structure of Acts of Imaginative Reading}

In the following, I seek to demonstrate that the dynamic pattern of repetition in Four Quartets which was analyzed by William Spanos in his influential deconstructive reading of the text is in fact a pattern of Eliot's reparative reading of the text's semi-autonomous elements which is based on inter- and intratextual feedback processes: composed over a time span of seven years, Four Quartets is the outcome of the author's creative readings of its existent and emerging parts, it is the product of Eliot's perpetual negotiation of shifting interpretive horizons. In The Use of Poetry and the Use of Criticism (1932-1933), Eliot describes the process of poetical composition as a creative reading process which undermines the concept of a stable, unchanging author intention:

7 By 1938, Eliot had acquired a "community and readership" in a church discussion forum (The Moot) whose members were readers whom Eliot knew and could address personally. Thus, Eliot by 1938 found himself in a situation which differed from his earlier intellectual isolation. The Moot provided Eliot with a personal context in which "political ideas could be shared and moderated, not merely flung out as provocations" (Scott 1994, 70). Eliot's contact with readers who were personally well-known to him might in part explain the personal voice speaking at times in Four Quartets. Cleo McNelly Kearns emphasises that at the time when Eliot was composing Four Quartets, he was cultivating an "art that is respectful of its audience”, see McNelly Kearns 1994, 92. 
What a poem means is as much what it means to others as what it means to the author; and indeed, in the course of time a poet may become merely a reader in respect to his own work, forgetting his original meaning - or without forgetting, merely changing. (Eliot 1948, 130)

The intra- and intertextual feedback processes of creative reading performed by the author neither produce a fixed, unalterable arrangement of the semi-autonomous parts and semantic units of the text nor a closure of meaning. Instead, although Four Quartets can be read as a progressive narrative structure, it can also be accessed at different points. The processes of a re-arrangement, exchange and re-interpretation of textual elements (signifiers, lines, phrases, images) carried out by Eliot can be continued by readers, they constitute what Roland Barthes has defined as an ideal text (Barthes 1974, 5-6). Eliot's poem inspires acts of reading which are based on intra- and intertextual hermeneutic feedback processes and which continuously import and export semantic units and signifiers from as well as into other texts. The variations, combinations and re-interpretations of the textual elements in Four Quartets undermine fixed notions of a "beginning" and an "end" of meanings and texts as well as of acts of reading. In section five of "Little Gidding", Eliot describes this open-ended interweaving of beginnings and endings as a process which defines acts of poetical composition as well as acts of imaginative reading. At the same time, the infinite hermeneutic process described here is based on a recognition of and a creative involvement with illegibility:

\footnotetext{
What we call the beginning is often the end And to make an end is to make a beginning. The end is where we start from.

Every phrase and every sentence is an end and a beginning, Every poem an epitaph. And any action Is a step to the block, to the fire, down the sea's throat Or to an illegible stone: and that is where we start. (“Little Gidding” V.214-227)
}

My own reading of Four Quartets is neither dictated nor predetermined but rather inspired by the dynamic, provisional processes of signification in the text itself. In the following, I would like to show that Eliot's poem is defined by intra- as well as intertextual variations or readings of its elements which induce a provisional integration of semantic units and which inspire the production of semantic innovation. To illustrate this point, I will discuss the semantic process of the signifier "stillness" and its synonyms and syntactical variations in Four Quartets which is characterised by a dissemination of meaning as well as by a novel and tensional integration of polysemy. This semantic process shows strik- 
ing structural similarities with the feedback processes of reparative reading in which "powerful part-objects" amalgamate to produce unprecedented, impertinent nexuses of meaning and novel self images (Sedgwick 2003, 128, 150; Barber 1997, 403, 410, 424).

The meaning of the signifier "stillness" in the fifth section of "Little Gidding" contains traces and echoes of its variations (including "silence" and "soundless") in all other Quartets. The meaning of "stillness" in the final passage of "Little Gidding" can neither be reduced to a metaphysical presence nor to an immobile or arrested signifier (see "Burnt Norton" II.62, III.90-102 V.137146 and "East Coker" III.118-121, 123-128) nor to the deferral of a presence of meaning as in the use of the variations of "stillness" and "silence" in "East Coker" (I.22,23, 47, 48; V.204-206) and "The Dry Salvages" (I.34, II.49, 50, 63, 82). The use of "stillness" at the end of section five of "Little Gidding" signifies a pause "between two waves of the sea", an interval between the noise of gliding signifiers which pervaded "The Dry Salvages" (I.34, II.49, 50, 63, 82). It enables (and is produced by) the attentive perception of novelty and plenitude through a mediration of intense experiences of intersections between time and eternity which are represented in "Burnt Norton" (I.35-41, II.62-82, V.169-175) and "East Coker" (III.123-133). In "Burnt Norton" and "East Coker", "stillness" and its variations refer to techniques of meditation and contemplation as well as to experiences of a peace of mind and of enlightenment. Although the signifier "stillness" is absent from "The Dry Salvages", the Quartet contains moments of silence: Krishna's self-revelation, another instance of an intersection of time and eternity, is inaudible and yet perceived by Arjuna as a descant, as "a voice descanting (though not to the ear ... and not in any language)". ${ }^{8}$ Although "stillness" in section five of "Little Gidding" is framed by quotations from Christian mystical texts (Cloud of Unknowing and the Revelations of Julian of Norwich), its meaning is not limited to Christian eschatology. ${ }^{9}$ It spans cross-cultural spiritual practices of meditation and contemplation which are heterogeneous and yet universal and which lead to joyful experiences of love and enlightenment in a merging of the self with God or the universe in Christianity, in Hinduism (where meditation can lead to an "equal mind", see "The Dry Salvages" III) ${ }^{10}$ and Bud-

8 For another moment of silence or stillness which occurs in an intense, contemplative perception of music see "The Dry Salvages" V.210-211.

9 My reading of Four Quartets differs from that of Douglas Atkins. He argues that Eliot's poem focuses on the understanding of the Incarnation and on Christian eschatology, see Atkins 2010, 9, 34, 37.

10 The experience of Brahman is not clearly defined in Hindu and Buddhist texts, but it is described in very general terms as a oneness with the universe which manifests itself as bliss, stillness, a peace of mind or as enlightenment. It is often symbolised by the sacred lotus. Eliot's 
dhism (The Cloud of Unknowing contains elements which are related to Buddhist meditation).

The stillness described in section five of "Little Gidding" is closely related to mystical practices of contemplation and meditation, yet it goes beyond mystical experiences because it also refers to an attitude of creative attentiveness towards texts (to religious, philosophical or literary texts) in which unprecedented connections between semantic oppositions (e.g. between "time" and "eternity") can be produced in intra- and intertextual acts of reading. The last section of "Little Gidding" introduces a hermeneutic practice which is based on a partial (or "half") perception of the text's polyphonic voices:

With the drawing of this Love and the voice of this Calling

We shall not cease from exploration

And the end of all our exploring

Will be to arrive where we started

At the source of the longest river

The voice of the hidden waterfall

And the children in the apple-tree

Not known, because not looked for

But heard, half-heard, in the stillness

Between two waves of the sea.

Quick now, here, now, always -

A condition of complete simplicity

(Costing not less than everything)

(“Little Gidding” V.139-154).

Eliot's discussion of acts of partial perception can be productively connected with Ricœur's notion of a creative 'partial appropriation' of texts in acts of reading (Ricœur 1973b; Ricœur 1976, 43-44; Meyer and Deshen 2010, 8). In contrast to Mike Logan's reading of these lines from "Little Gidding", I would like to argue that the hermeneutic practice of attentive receptiveness and "stillness" described by Eliot does not uncover a "void" or a "presence of meaning" (Logan 1996, 46) but generates intense experiences of novelty and plenitude in creative acts of reparative reading ("Little Gidding" V.246-248). In both "The Dry Salvages" and "Little Gidding", such experiences go beyond confessional and cultural boundaries and they produce novel conditions of "complete simplicity". In Eliot's text, this "simplicity" which costs "not less than everything" is not pro-

pun "lotos rose" in "Burnt Norton" (I.36) might allude to the sacred lotus and its symbolic meaning. In Hinduism, the lotus is a polyvalent signifier which represents divine beauty and purity created from the mud, it spans the heterogeneous meanings of sensuality, innocence, unattached duty, sacredness, purity and fertility, see Sena 1992. 
duced by a reduction but by a condensation of meaning. This condensation or concentration ${ }^{11}$ of meaning resembles the "additive and accretive" nature of the reparative impulse which avoids semantic reduction and "wants to assemble and confer plenitude on an object that will then have resources to offer to an inchoate self" (Sedgwick 2003, 149). In "Little Gidding", such dense experiences of "complete simplicity" comprise the mystic practices of meditation and contemplation in different religions and philosophies but they also comprise the joyful acts of imaginative reparative reading which generate novel insights, e.g. through the reader's construction of semantic connections between the different spiritual and philosophical practices discussed in Four Quartets. Thus, the hermeneutic and ethical practice of signification which defines "Little Gidding" can be described as anti-separatist. Eliot's poem is pervaded by an atmosphere of affective plenitude which connects heterogeneous affects and attitudes like joy, love, interest, care, hope, anger, distress, fear and humiliation and which emanates from what Stephen Barber in his reading of Virginia Woolf's The Years and Between the Acts has called a "joyful experimentation with being" (Barber 1997, 405), that is, from a novel and impertinent integration of semantic oppositions. The processes of signification in "Little Gidding" in which meaning is created in intra- and intertextual feedback processes of acts of reading go beyond, resist and even invert "regulatory procedures of labelling" which produce the binarisms of religious and cultural difference. In addition, they connect spiritual practices of meditation with hermeneutic practices of reading.

Eliot's final section of "Little Gidding" is characterised by new accesses to representations of intense experiences of intersections between time and eternity in Four Quartets. They create these experiences anew in different forms through acts of intra- and intertextual reading. ${ }^{12}$ The phrase "children in the apple-tree" is imported from Eliot's poem "New Hampshire" which is included in Landscapes (1935-1936), but it also combines elements from Four Quartets ("Children" occurs in "Burnt Norton", "apple" in "The Dry Salvages" und "tree" is derived from "axle-tree" in "Burnt Norton"). The phrase alludes to the moments of epiphany in "Burnt Norton" (I.35-41, V.169-175) but also to the innocent voices of the saints in Dante's Divine Comedy.

11 In "Tradition and the Individual Talent", Eliot has described the process of poetical production in terms of a "concentration ... of a very great number of experiences" which produces "a new thing resulting from the concentration" (see Eliot 1992, 764).

12 In "The Dry Salvages", Eliot writes about moments of "sudden illumination" which are accessed through creative acts of memory in which "approach to the meaning restores the experience/In a different form" ("The Dry Salvages" II.90-96). This passage can be related to Ricœur's description of the act of reading as an event or experience, see Ricœur 1991, 57-58. 
The final passage of "Little Gidding" assembles voices and images of intense experiences of novelty and plenitude from the other Quartets: the phrase "The voice of the hidden waterfall" ("Little Gidding V.143) is a variation of a line from "The Dry Salvages" (V.210). The final passage of "Little Gidding” combines images of places of plenitude and intensity ${ }^{13}$ which are derived from other Quartets (e.g. from the images of the "rose-garden" in "Burnt Norton" or from the images related to the Mississippi, the sea and the seacoast of Massachusetts in the first and second sections of "The Dry Salvages"), yet the new access to these images "through the unknown, remembered gate" 14 makes readers "know the place for the first time" ("Little Gidding" V.243, 242). The intense experiences depicted in the final passage of "Little Gidding" allude to the moments of epiphany in "Burnt Norton” (I.36-41, 169-175), "East Coker" (III.123-131) and "The Dry Salvages” (V.206-212), but they also comprise Arjuna's perception of Krishna's self-revelation on the battlefield of Kurukshetra in the third section of "The Dry Salvages", the "moments of agony" and "primitive terror" in history which are described in the second section of "The Dry Salvages" as well as other intense experiences of plenitude and novelty which are not "known" but "halfheard" and "remembered" from Four Quartets and from other texts ("Little Gidding” V.243, 249, 250).

Eliot's text shows that it is precisely the partial, incomplete nature of the perception and representation of the intersections between "time" and "eternity" which makes them productive sources of the ongoing processes of unprecedented, provisional and tensional meaning construction.

The image of the "tongues of flame" which fold into a "knot of fire" in the last lines of "Little Gidding" is very rich in intertextual as well as intratextual meaning. It alludes to the destructive fire of the Blitz and condenses the textual energy which provokes a dissemination of meaning. ${ }^{15}$ At the same time, it evokes the meaning of fire as a symbol of love (in the references to the shirt of Nessus and to the apotheosis of Hercules in "Little Gidding" IV.205-213 as well as to the beatific vision in Dante's Divine Comedy in the last line of the Quartet) and of a creative force of spiritual transformation in the phrases "pentecostal fire” ("Little Gidding” I.10), "purgatorial fires” ("East Coker V.165-166) and "refining fire" ("Little Gidding" II.145). Thus, the image of the "tongues of flame" which fold into a "knot of fire" does not only express destruction and disinte-

13 "Through the unknown, remembered gate ... At the source of the longest river ... the hidden waterfall ... the apple-tree ... the sea" ("Little Gidding” V.243-251). For a discussion of Gilles Deleuze's notions of intensity and plenitude see West-Pavlov 2009, 209-244.

14 "Gate" here alludes to "first gate" in "Burnt Norton" I.20.

15 This meaning of the fire image was emphasised by Logan 1996, 46. 
gration but also the power of transformation which language holds. Being generated through semantic processes in which polyphonic "tongues" are "infolded", it anticipates Deleuze's concept of the fold which spans "identity and difference, subject and environment, inner and outer, singularity and multiplicity" (West-Pavlov 2009, 30, 233-239). In the following, I seek to demonstrate that the unprecedented nexus of meaning (the "one" which connects "fire" and "rose") in the final line of "Little Gidding" is a dense emblematic structure which is produced by a provisional and tensional integration of polysemy:

And all shall be well and

All manner of thing shall be well

When the tongues of flame are in-folded

Into the crowned knot of fire

And the fire and the rose are one.

(“Little Gidding” V.155-159)

The signifiers "fire" and "rose" in Eliot's Four Quartets invite allegorical readings, but they have accumulated a plenitude of meaning which is produced in all of their intra- and intertextual variations and which goes beyond allegorical meaning. ${ }^{16}$ However, the plenitude of meaning produced in the semantic pro-

16 The signifier and image "rose-garden" ("Burnt Norton" I.14) is transformed through processes of 'atomization', variation, punning and recombination into in "rose leaves" ("Burnt Norton” I.16,) "roses" ("Burnt Norton” I.28), "lotos rose" ("Burnt Norton” I.36), "Primrose” ("Burnt Norton” III.112), "late roses” (“East Coker” II.56), "burnt roses” (“Little Gidding” II.55), "smoke arose" ("Little Gidding” II.85), "moment of the rose" ("Little Gidding” V.232), "Royal Rose" ("The Dry Salvages" III.126), "the flame is roses and the smoke is briars" ("East Coker" IV.166), "briar rose" ("The Dry Salvages" I.26) "the rose" ("Little Gidding” V.159) and "the spectre of a Rose” ("Little Gidding” III.184), a phrase which reminds readers of William Butler Yeats's mythological poems about Ireland and his love for Maude Gonne, above all of "The Secret Rose" (1897). Yet Eliot creates even more variations of the signifier "rose", especially of "rose leaves" which are partly transformed into "leaves". These variations expand the meaning of "rose" and "rose leaves" through the use of derivatives like "dead leaves" ("Burnt Norton" I.24; "Little Gidding” II.83), "leaves were full of children” ("Burnt Norton” I.40), "Yellow leaves of a book" ("The Dry Salvages” III.130), "tea leaves” and "metal leaves” ("Little Gidding” II.87). The signifier "burnt" from the title of the first Quartet "Burnt Norton" is transformed into "burns" in "burns before the ice-cap reigns" ("East Coker" II.67), into "burning" in "a lifetime burning" and into "burnt" as a part of "burnt roses" ("Little Gidding" II.55). It is connected to all the variations and combinations of "fire" which comprise "new fires" ("East Coker" I.5), "Old fires" ("East Coker” I.6), "bonfire” ("East Coker” I.27), "purgatorial fires” ("East Coker” IV.165), "round the fire” ("East Coker” I.33), "destructive fire” ("East Coker” II.66), "frost and fire” ("Little Gidding” I.4), "Pentecostal fire” ("Little Gidding” I.10), "tongued with fire” ("Little Gidding” I.51), "refining fire" ("Little Gidding” II.145), "knot of fire” ("Little Gidding” V.258), "water and fire" ("Little Gidding” II.70, 72, 74), "death of water and fire" ("Little Gidding” II.77), "to be redeemed from fire by fire” ("Little Gidding” IV.206), "Consumed by either fire or fire” ("Little Gidding” 
cesses of "fire" and "rose" incorporates their allegorical meanings and "interdigitates” productively with them (Sedgwick 2003, 145).

In Four Quartets, the variations of "rose" signify different forms of love or ecstasy which can be related to Silvan S. Tomkins's notion of positive affects (joy or enjoyment, interest and excitement), i.e. the love between individuals, the love of individuals for their country as in "Royal Rose" and God's love for mankind as in Eliot's allusions to the beatific vision in Dante's Divine Comedy ("Little Gidding" V.159). ${ }^{17}$ Thus, the variations of "rose" can be read as symbols of Christianity and England, ${ }^{18}$ but the expanded conception of love in "Little Gidding" which goes beyond an attachment to "self", "things" and "persons" is a "love beyond desire", it transgresses national and confessional boundaries ("Little Gidding” III.152, 153, 157-161). In Four Quartets, the rose is a symbol of many different forms of love, but the variations "rose leaves" or "leaves" also refer to experiences of destruction as in the allusions to the Blitz ("Little Gidding" II.83, 87). The variations of "fire" (including the metonymic variations "ashes", "flame" and smoke") signify destruction and death as well as the negative affect of rage but also the hopeful and joyful experiences of regeneration, transformation and rebirth. ${ }^{19}$ The semantic contexts of Christian religion and of

IV.213), "a step to the block, to the fire" ("Little Gidding" V.226), "the fire and the rose are one" ("Little Gidding" V.259). The signifiers "burn" and "fire" with all their variations and combinations are connected to their metonymic, metaphoric and syntactic variations, to "smokefall" ("Burnt Norton” II.88), "smoke” ("East Coker" IV.166; "Little Gidding” II.83), “ashes" ("East Coker" I.6), "ash” ("Little Gidding” II.54-55), "flames” ("East Coker” I.34), "flame” ("East Coker" IV.166; "Little Gidding” IV.201), "shirt of flame” ("Little Gidding” IV.210); "tongues of flame” ("Little Gidding" V.257) and "brief sun flames the ice" ("Little Gidding” I.5). Eliot expands the meaning of "burn" and "fire" in his variations of "heat" and "light", see "sunlight" ("Burnt Norton” I.35), "heart of light” ("Burnt Norton” I.37), "white light” ("Burnt Norton” II.73), "daylight" ("Burnt Norton” III.93), "light to light", "light is still” ("Burnt Norton IV.135), "shaft of sunlight” ("Burnt Norton” I.169), "electric heat” ("East Coker” I.19), "sultry light” ("East Coker” I.20), "starlight” (“East Coker” V.197), "lamplight” ("East Coker” V.198), "heat” ("East Coker” I.48) and "the darkness shall be the light" ("East Coker" III.128).

17 "Royal Rose" in section three of "The Dry Salvages" refers to the heraldic emblem of the Tudor dynasty and the end of the Wars of the Roses (see Reibetanz 1970, 121). It is the traditional heraldic emblem for England. According to Bonamy Dobrée, there are "three different roses in the poem: the sensuous rose, the socio-political Rose ... and the spiritual rose: and the three have got to be in some way identified as one” (see Bonamy Dobrée 1966, 86).

18 See Chew 1937.

19 In "Little Gidding", the heterogeneous notions of selfish, possessive and jealous love (represented by Nessus and Deianeira) which is the origin of torment and destruction (a poison) and of selfless, merciful love or devotion (represented by Hyllus) symbolised by the flames which burn the body and free the soul ("Who then devised the torment? Love./Love is the unfamiliar Name/Behind the hands that wove/The intolerable shirt of flame/Which human power cannot 
interconfessional and intercultural spiritual practices add the meanings 'hope', 'love', 'transformation', 'regeneration' and 'rebirth' to the signifier "fire" as in the allusions to purgatory and the "refining fire" ("East Coker" IV.165; "Little Gidding" II.145), to the beatific vision in Dante's Divine Comedy ("Little Gidding" V.257-259) and above all to the Pentecostal "tongues" of "flame" ("Little Gidding” IV.201-202, V. 257).

The meanings of "fire" and "rose" in the final line of "Little Gidding" never become congruent or identical, ${ }^{20}$ they comprise the semantic richness which they have accumulated in the semantic processes of image variation and image reading in Four Quartets. The "one" or whole created through an integration of the heterogeneous semantic units of "fire" and "rose" is a semantic innovation. However, it is not the connection of "fire" and "rose" in itself which is new, both symbols are combined in Canto 31 of Dante's Divine Comedy in the image of the saints who are arranged in the pattern of the leaves of a white rose and who contemplate God's eternal light with glowing faces. The novelty in Eliot's line is the way in which "fire" and "rose" are connected: they form a whole or unit which is held together by a tension between its components and its components remain semi-autonomous. In his reading of Eliot's integrative aesthetics which pervades "Little Gidding", Michael North maintained that "the part becomes the whole, representing it precisely because of its difference" (North 1991, 127). However, in the final line of "Little Gidding", one part does not displace the other and the whole does not replace or absorb the parts which it contains. The novel wholes which Eliot projects in the last lines of "Little Gidding" ("tongues of flame are infolded/Into the crowned knot of fire", "the fire and the rose are one", "Little Gidding" V.257-258) achieve a tensional and provisional integration of semantic oppositions and of polysemy. The wholes which are held together by a flexible tension between their semi-autonomous semantic units inspire ongoing exchanges, re-arrangements and re-combinations of the of parts and the whole as well as ongoing transformations of the relation between the parts and the whole: the signifiers "tongues of flame" and "fire" retain their polysemy and centrifugal deconstructive energy or pull, they provoke ongoing reading processes in which novel and provisional nexuses of meaning can be produced.

remove"; "Little Gidding” IV.206-211) is related to the story of the shirt of Nessus and the apotheosis of Heracles which is the central subject of Sophocles's tragedy Women of Trachis. It was translated and adapted by Ezra Pound in 1956.

20 My reading differs from that of Julia M. Reibetanz who argues that "in this amazing unity, fire and rose are each themselves and yet the other" (see Reibetanz 1970, 186). 
The first, second and fourth sections of "Little Gidding" contain similar tensional nexuses of meaning. The oxymora "dark dove with the flickering tongue" (II.81), "midwinter spring" (I.1), "pole and tropic" (I.3), "frost and fire" (I.4), "windless cold that is the heart's heat" (I.6), "pentecostal fire/In the dark time of the year" (I.10-11), "21 "melting and freezing" (I.11) and "blossom of snow" (I.15-16) span negative and positive affects which underlie the contrastive semantic fields of the blitzkrieg and of Pentecost in "Little Gidding" (II.81, 82, IV.200-203). They express the dense atmosphere of interruptive affective variety in the fourth Quartet, ${ }^{22}$ and they project overreaching nexuses between heterogeneous and even contrastive affects. The composition as well as the reading and actualisation of the oxymoron (which is structurally closely related to the conceit) give rise to the neutral or "resetting” affect of surprise (Tomkins 1995a, 74) and inspire the joyful creation of semantic innovation "in front of the text" (Ricœur 1973b, 140). The following passage from section four of "Little Gidding" contains oxymora which violate semantic propriety (Ricœur 1973a, 106):

\footnotetext{
The dove descending breaks the air

With flame of incandescent terror

Of which the tongues declare

The one discharge from sin and error.

The only hope, or else despair

Lies in the choice of pyre or pyre

To be redeemed from fire by fire.

(“Little Gidding” IV.200-206)
}

The flames of the blitzkrieg in this passage are not congruent with the flames of Pentecost which symbolise the Holy Spirit in the Acts of the Apostles (2: 1-31), and yet they are connected with each other because of their difference and tension: in Eliot's reparative amalgamation of contrastive images, the "flame of incandescent terror" does not signify a punishment ${ }^{23}$ of or a judgement on but a

21 Here, Eliot seems to allude especially to the firestorm of the Blitz shortly after the Christmas season of 1940.

22 Eliot composed the fourth Quartet in the context of the Blitzkrieg-attacks on London which he witnessed as a fire watcher. Consequently, "Little Gidding" was produced in an atmosphere of negative affects (distress/anguish, fear/terror, shame/humiliation) and expresses traumatic experiences which affected many British citizens. At the same time, it is characterised by an atmosphere of positive affects (interest/excitement, and joy/enjoyment) and their related optimistic attitudes (especially hope) and values as well as by the "resetting" affect of surprise (see Tomkins 1995a, 74).

23 See e.g. Thomas Vincent's interpretation of the Great Fire in London in 1666 as an expression of God's punishment of sins (Vincent 1811). 
"discharge from", that is, a release, liberation and relief from "sin and error", it offers resources (comfort and hope) to damaged selves and cultures.

The image of the "tongues of flame" might be read - like the image combining the dive bomber and the Pentecostal dove ("the dark dove with the flickering tongue", "Little Gidding” II.81) - as a novel nexus of meaning held together not so much by similarity as by difference, tension and centrifugal energy: the "tongues of flame" comprise the semantic fields 'destruction', 'transformation', 'regeneration' and 'redemption' and they point to the regenerative and transforming power of language as well as to the sensual and intellectual pleasure derived from punning, deconstructive reading ${ }^{24}$ or from the construction of novel combinations of semantic units. When the "tongues of flame" have "infolded" into the "crowned knot of fire", the heterogeneous meanings of "fire" and "rose" can indeed become "one", yet their relation is different from that in "East Coker" where "the flame is roses and the smoke is briars" (IV.166). Because of its condensed and rich religious, political, philosophical and spiritual meaning, the "one" composed of "fire" and "rose" in the final line of "Little Gidding" is a novel nexus of meaning produced by intra- and intertextual processes of reading which connect semi-autonomous semantic units from Four Quartets and many other texts. In addition, Eliot's "one” is, like Deleuze's fold, a novel material and spatial structure. As such, it represents a synthesis of hermeneutics and semiotics: it is an emblematic structure which is produced by and gives rise to intra- and intertextual processes of image variation and imaginative image reading. It does not only have a "semiological dimension" or a "sense" but it inspires the creation of meaning in ongoing processes of creative reading (Ricœur 1991, 57-58). Eliot's "one" is no longer a traditional image which refers to a meaning that is created outside of or behind the text, instead, it means by itself, it inspires novel, provisional and tensional integrations of heterogeneous semantic units in acts of reading.

\section{Conclusion}

As I hope to have demonstrated, the hermeneutic processes of signification at work in Four Quartets produce novel nexuses of meaning which resemble those constructed in acts of reparative reading: Eliot's final line of "Little Gidding" does not only make sense if it is connected to the structural pattern of the Incar-

24 For the pleasures derived from deconstructive reading, see Roland Barthes 1975. 
nation (Atkins 2012), to experiences of unio mystica or to the beatific vision in Dante's Divine Comedy and to Dante's image of the white rose which integrates fire energy, light and rose shape (Reibetanz 1970, 186; Logan 1996, 42). It is a Prägung zum Sein and it anticipates structures of "tensional integrity" or "tensegrity" which constitute the "architecture of life" (Ingber 1998). Since the beginning of the twentieth century, structures of tensional integrity have become the objects of analysis in the humanities and the natural sciences, they can be observed in the novel self or body images created in queer or migrant autobiographies as well as in the novel self images constructed by patients during psychotherapy (Sedgwick 2003, 128), in the structure of a sonata (Moody 1994, 143), in the complex whole of a culture or a nation which is formed through the integration of semi-autonomous units (subcultures and small-scale communities) or in the communal structures which emerge in the third space of intercultural contact (Bhabha 1994, Chakrabarty 2002).

\section{Works Cited}

Alighieri, Dante. 2003. The Divine Comedy. Trans. John Ciardi. New York: The New American Library.

Atkins, Douglas G. 2012. Reading T. S. Eliot: Four Quartets and the Journey toward Understanding. New York: Macmillan, Palgrave.

Azzarello, Robert. 2012. Queer Environmentality: Ecology, Evolution and Sexuality in American Literature. Farnham: Ashgate Publishing.

Barthes, Roland. 1974. S/Z. Trans. Richard Miller. New York: Hill and Wang

Barthes, Roland. 1975. The Pleasure of the Text. Trans. Richard Miller. New York: Farrar, Straus and Giroux.

Barthes, Roland. 1992. "The Death of the Author”. Critical Theory Since Plato. Ed. Hazard Adams. Fort Worth: Harcourt Brace Jovanovich College Publishers. 1130-1133.

Barber, Stephen. 1997. “Lip-Reading: Woolf's Secret Encounters”. Novel Gazing: Queer Readings in Fiction. Ed. Eve Kosofsky Sedgwick. Durham: Duke University Press. 401-443.

Bhabha, Homi K. 1994. The Location of Culture. London: Routledge.

Buell, Lawrence. 2002. "What We Talk About When We Talk About Ethics". The Turn To Ethics. Ed. Marjorie Garber, Beatrice Hanssen, Rebecca L. Walkowitz. New York: Routlede. 1-14.

Cassirer, Ernst. 1923. Die Philosophie der symbolischen Formen. 3 vols. Berlin: Cassirer.

Chakrabarty, Dipesh. 2002. Habitations of Modernity: Essays in the Wake of Subaltern Studies. Chicago: The University of Chicago Press.

Chew, Samuel. 1937. The Crescent and the Rose: Islam and England during the Renaissance. New York: Oxford University Press.

Dobrée, Bonamy. 1966. “T. S. Eliot: A Personal Reminiscence”. T. S. Eliot: The Man and His Work. Ed. Allen Tate. New York: Delacorte Press.

Eliot, T. S. 1939. “Last Words”. The Criterion 18: 269-275.

Eliot, T. S. 1943. Four Quartets. New York: Harcourt, Brace and World. 
Eliot, T. S. 1948. The Use of Poetry and the Use of Criticism. London: Farber and Farber.

Eliot, T. S. 1967. Christianity and Culture. London: Harcourt.

Eliot, T. S. 1992. "Tradition and the Individual Talent”. Critical Theory since Plato. Ed. Hazard Adams. Fort Worth: Harcourt Brace. 761-764.

Ingber, Donald E. 1998. "The Architecture of Life”. Scientific American 278.1: 48-57.

Lassen, Christian. 2013. "The Passion of Saint Kitten, or: Desperately Seeking Mitzi, the Phantom Lady. Camp Responses to Interpellation and Subjection in Neil Jordan's Breakfast on Pluto". Anglistentag 2012 Potsdam Proceedings. Ed. Katrin Röder and Ilse Wischer. Trier: WVT. 81-89.

Logan, Michael M. 1996. "Eliot's Fire Paradigm of Poetry, the Cosmos, Poststructuralism". Yeats Eliot Review 14.2: 2-13, 43-48.

McNelly Kearns, Cleo. 1994. "Religion, Literature and Society in the Work of T. S. Eliot". The Cambridge Companion to T. S. Eliot. Ed. A. David Moody. Cambridge: Cambridge University Press. 77-93.

Melaney, William D. 2002. “T. S. Eliot's Poetics of Self: Reopening Four Quartets”. Alif: Journal of Comparative Poetics 22: 148-168.

Meyer, Kinereth and Rachel Salmon Deshen. 2010. Reading the Underthought: Jewish Hermeneutics and the Christian Poetry of Hopkins and Eliot. Washington: The Catholic University of America Press.

Moody, A. David. 1994. "Four Quartets: music, word, meaning and value”. The Cambridge Companion to T. S. Eliot. D. A. David Moody. Cambridge: Cambridge University Press.

North, Michael. 1991. The Political Aesthetic of Yeats, Eliot, and Pound. Cambridge: Cambridge University Press.

Nünning, Ansgar. 1993. "Renaissance eines anthropomorphisierten Passepartouts oder Nachruf auf ein literaturkritisches Phantom? Überlegungen uns Alternativen zum Konzept des 'implied author'”. Deutsche Vierteljahrsschrift für Literaturwissenschaft und Geistesgeschichte 67: 1-25.

Reeves, Christopher. 2010. "Redeeming Time: Winnicott, Eliot, and the Four Quartets". American Imago: Psychoanalysis and The Human 67.3: 375-397.

Reibetanz, Julia Maniates. 1970. A Reading of Eliot's Four Quartets. Ann Arbor: UMI Research Press.

Ricœur, Paul. 1967. The Symbolism of Evil. Trans. Emerson Buchanan. New York: Harper and Row.

Ricœur, Paul. 1970. Freud and Philosophy: An Essay on Interpretation. Trans. Denis Savage. Yale: Yale University Press.

Ricœur, Paul. 1973a. “Creativity in Language”. Philosophy Today 17: 97-111.

Ricœur, Paul. 1973b. “The Hermeneutical Function of Distanciation”. Philosophy Today 17: 129-141.

Ricœur, Paul. 1976. Interpretation Theory: Discourse and the Surplus of Meaning. Fort Worth: Texas Christian University Press.

Ricœur, Paul. 1984. Time and Narrative I. Trans. K. McLaughlin and D. Pellauer. Chicago: University of Chicago Press.

Ricœur, Paul. 1985. Time and Narrative II. Trans. K. McLaughlin and D. Pellauer. Chicago: University of Chicago Press.

Ricœur, Paul. 1991. "What is a Text? Explanation and Understanding”. Reflection and Imagination: A Ricœur Reader. Ed. Mario J. Valdés. Hertfordshire: Harvester Wheatsheaf. 43-64. 
Scott, Peter Dale. 1994. "The Social Critic and his Discontent". The Cambridge Companion to

T. S. Eliot. Ed. A. David Moody. Cambridge: Cambridge University Press. 60-76.

Sedgwick, Eve Kosofsky and Adam Frank. 1995. "Shame in the Cybernetic Fold: Reading Silvan Tomkins". Shame and its Sisters: A Silvan Tomkins Reader. Ed. Eve Kosofsky Sedgwick and Adam Frank. Durham: Duke University Press. 1-28.

Sedgwick, Eve Kosofsky. 1997. "Paranoid Reading and Reparative Reading, or, You're So Paranoid, You Probably Think This Essay Is About You”. Novel Gazing: Queer Readings in Fiction. Ed. Eve Kosofsky Sedgwick. Durham: Duke University Press. 1-37.

Sedgwick, Eve Kosofsky. 2003. "Paranoid Reading and Reparative Reading, or, You're So Paranoid, You Probably Think This Essay Is About You”. Touching Feeling - Affect, Pedagogy, Performativity. Durham: Duke University Press. 123-151.

Sena, Vinod. 1992. "The Lotos and the Rose: The Bhagavad Gita and T. S. Eliot's Four Quartets". The Fire and the Rose: New Essays on T. S. Eliot. Ed. Vinod Sena and Rajiva Verma. Delhi: Oxford University Press. 180-189.

Spanos, William V. 1978. "Hermeneutics and Memory: Destroying T.S. Eliot's Four Quartets". Genre 11.4: 523-574.

Stern, David. 1988. "Midrash and Indeterminacy”. Critical Inquiry 15: 132-161.

Tomkins, Silvan S. 1995a. "What are Affects?" Shame and its Sisters: A Silvan Tomkins Reader. Ed. Eve Kosofsky Sedgwick and Adam Frank. Durham: Duke University Press. 33-74.

Tomkins, Silvan S. 1995b. "The Body Image and Phantom Limbs". Shame and its Sisters: A Silvan Tomkins Reader. Ed. Eve Kosofsky Sedgwick and Adam Frank. Durham: Duke University Press. 241-250.

Valdés, Mario J. 1991. “Introduction: Paul Ricœur’s Post-Structuralist Hermeneutics”. Reflection and Imagination: A Ricœur Reader. Ed. Mario J. Valdés. Hertfordshire: Harvester Wheatsheaf. 3-40.

Vincent, Thomas. 1811. God's Terrible Voice in the City. Bridgeport: Lockwood and Backus. West-Pavlov, Russell. 2009. Space in Theory: Kristeva, Foucault, Deleuze. Amsterdam: Rodopi. 